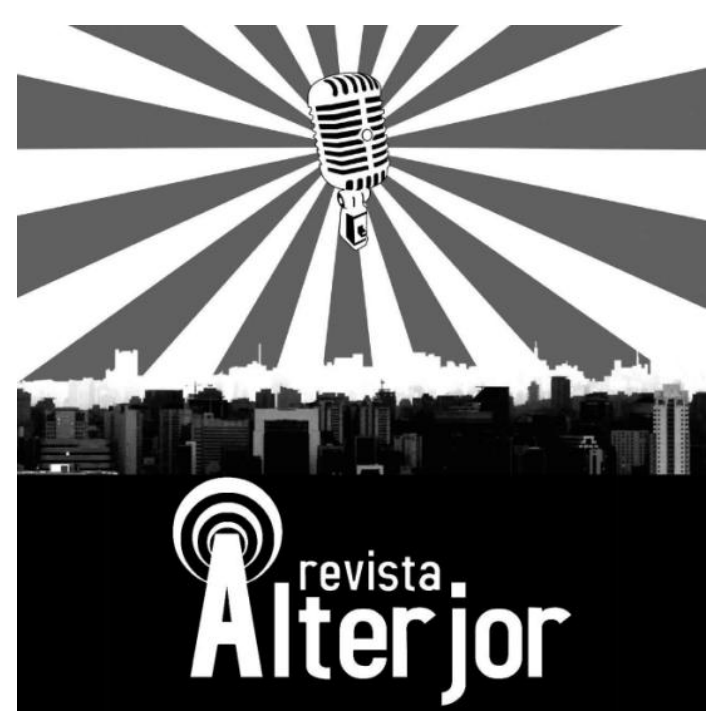

\title{
CRÔNICA
}

\section{DUAS LINHAS NARRATIVAS}

\section{Atílio Avancini ${ }^{1}$ \\ Nestor Müller ${ }^{2}$}

RESUMO: Esta crônica em duas etapas, e o ensaio fotográfico que as conclui, tem por objetivo discutir os efeitos da pandemia do coronavírus e do consequente isolamento social. O objetivo é promover reflexões, buscando ampliar os limites do espaço confinado para dimensões mais abrangentes. "Duas Linhas Narrativas" trabalha com binômios: duas tendências sociais, dois caminhos, dois autores, e duas linguagens, verbal e não-verbal.

PALAVRAS-CHAVE: Comunicação. Cultura. Ética. Jornalismo. Fotografia.

ABSTRACT: This chronicle in two stages, and photo essay that concludes them, aims to discuss the effects of the coronavirus pandemic and the consequent social isolation. The objective is to promote reflections, seeking to expand the confined space limits for more comprehensive paths. "Two Narrative Lines" works with binomials: two social trends, two paths, two authors and the languages, verbal and non-verbal.

KEYWORDS: Communication. Culture. Ethic. Journalism. Photography.

\footnotetext{
${ }^{1}$ Professor associado da ECA-USP, vice-coordenador do Programa de Pós-Graduação Meios e Processos Audiovisuais (ECA-USP) e supervisor acadêmico da Empresa Estudantil Jornalismo Júnior (ECA-USP). Autor dos livros: Rastros, Lavagem do Bonfim, Entre Gueixas e Samurais e Atílio Avancini - coleção artistas da USP n. 15. E-mail: avancini@usp.br

${ }^{2}$ Professor do Instituto Federal de São Paulo (IFSP), campus Araraquara, e membro do Núcleo de Estudos Afro-brasileiros e Indígenas (NEABI). É mestre e doutor em filosofia pela UFSCar. Tem formação em música e em psicologia existencial humanista. E-mail: nestorfilosofia @ yahoo.com.br
}

Revista ALTERJOR

Grupo de Estudos Alterjor: Jornalismo Popular e Alternativo (ECA-USP)

Ano 10 Volume 02 Edição $22 \quad$ Julho-Dezembro de 2020

Avenida Professor Lúcio Martins Rodriģues, 443, Cidade Universitária, São Paulo, CEP: 05508-020 
Os piores sustos passaram. Agora, final do mês de março de 2020, muitos lutos já foram chorados, estão sendo suportados, ou se avizinham. Planos matemáticos indicam, para cada região, os próximos custos mínimos, médios e máximos, em vidas e em rendas. Alguns países vão se acostumando com taxas decrescentes de contaminação. Outros passam por seus piores dias. Outros se preparam para convulsões já anunciadas, não menos terríveis. Algumas iniciativas de ajuda mútua se estendem. Aos poucos, a mentalidade ocidental se preparou para conviver longamente com a covid-19, enquanto avança a corrida pelas vacinas.

Mas para tão imenso cataclisma precisamos explicações. Vislumbro duas tendências, duas linhas narrativas que nós, ocidentais, começamos a esboçar, tentando entender o que está acontecendo. Delas apresento a seguir um esquema para pensarmos juntos. Procuro sondar as emoções que dão origem a uma e à outra, e como elas vão selecionando diferentes fatos para se articular com a realidade. Depois busco enxergar algumas de suas consequências, e por fim lhes atribuo um rosto, um nome que parece encarnar, ao menos neste momento em que escrevo, o caráter de cada uma delas.

A primeira narrativa nasce do terror com as perdas inesperadas, e da raiva que elas provocam ao destruir existências, planos, propriedades, seguranças. Seu fulcro é uma dor surda, entranhada, que após os gritos de desespero sente fome de encontrar apoios, e de buscar culpados: ressentimento que conduz à formação dos batalhões ávidos por um bode expiatório.

A segunda narrativa nasce da comoção, do luto vivido numa tristeza profunda e empática, e da pergunta que brota em quem se descobre numa verdadeira crise, quer dizer, diante de novas escolhas. Para esses resta o esforço de atravessar o emaranhado das dores, dos informes, dos sentimentos, até assomar a algum lugar mais claro, dentro de si mesmos, e em consonância com alguns parceiros: o espaço anímico em que as intuições mais genuínas e lúcidas podem vir à luz.

A primeira narrativa vai aos poucos juntando alguns fragmentos que apontam para a origem do mal. É evidente que ela está na cidade de Wuhan. As primeiras versões dessa narrativa se multiplicaram, infiltrando-se nos meandros do mercado popular, dos laboratórios de biossegurança, dos médicos impedidos de falar, das autoridades caladas durante aquelas três semanas de janeiro em que a covid-19 se alastrou, livre, como raio silencioso e mortífero. Então começaram a falar do vírus chinês, das contradições do governo chinês, de planos 


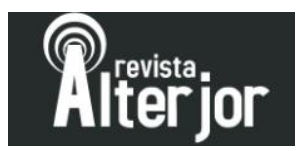

inconfessáveis, das ameaças que o crescente poder amarelo representa às nossas liberdades democráticas.

A segunda narrativa vai aos poucos se dando conta de como a eclosão da pandemia trouxe à tona insuficiências estruturais de nossas sociedades. As desigualdades que sempre estiveram aí não podem mais ser ocultadas, nem toleradas. $\mathrm{O}$ fato é que o vírus parece nos afligir por igual, a todos, mas enfim alguns têm meios para se defender e outros não. No vendaval de notícias, sobrevive a memória de que algumas pessoas, há cinco anos ou mais, estavam dizendo em bom som: depois do H1N1, depois do ebola, depois da gripe suína, virá uma nova pandemia que vai nos atingir em cheio.

A primeira narrativa vai satisfazer à nossa raiva. Vamos então escutar quem primeiro desconfiou das falhas do governo chinês e do modo tão rápido com que as contaminações foram lá estancadas, resultando em uma mortalidade relativamente baixa. E quem suspeitou da rapidez com que as indústrias chinesas retomaram sua produção, passando a vender aqueles insumos médicos que as outras nações vieram a necessitar.

No processo, essas vozes sempre desdenharam do vírus, negaram-se às incômodas medidas de isolamento social, indicaram remédios milagrosos. Suas palavras veementes, suas mensagens repetidas, atenderam nosso pavor. E então deixamos de ver como essas vozes nos conduziram às medidas desencontradas que irão resultar nas maiores tragédias. Seus autores se tornaram campeões de uma verdade erguida contra o dragão chinês, e prometeram reordenar todas as coisas. E assim começamos a receber os decretos e controles que a salvação da pátria parecia requerer.

A segunda narrativa vai ser tecida por nossa resiliência, e pela aceitação de nossas próprias falhas. Por um lado, o período de quarentena permitiu-nos descobrir como a vida pôde ser mais simples, silenciosa, personalizada. Enfim passamos semanas sem o frenesi das multidões, conseguimos enfrentar medos viscerais, e ainda estamos vivos, tristes, mas supreendentemente atentos. Por outro lado, temos que nos render ao bom senso de reconhecer como não prestamos a devida atenção àquelas outras vozes, que nos alertavam para a iminência de uma pandemia. E assim podemos chegar a descobrir que a ignorância - a nossa ignorância -, é a verdadeira responsável pelo volume de danos que agora nos esmaga. Pois podiam ter sido evitados.

Minhas informações são muito restritas, o que me leva a eleger dois ícones provisórios para representar as duas tendências. A primeira narrativa se ergue, ruidosa, nos discursos do 


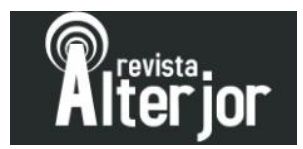

presidente norte-americano Donald Trump e seus aliados, atendendo aos anseios de todos os que desejam voltar à vida "normal". Mas o que está incluído nesses discursos é a ignorância disse Donald Trump, 19 de março de 2020, na Casa Branca: "ninguém sabia que teríamos uma pandemia ou epidemia desse tamanho" (TRUMP, 2020). E também ódio, manifesto na cega decisão de fechar ainda mais as fronteiras, de olvidar as interdependências, de incrementar as indústrias bélicas capazes de atacar qualquer movimento ameaçador. O que se esconde nesse tipo de discurso é enfim a vontade de não perder o domínio sobre os outros, é a antiga falta de respeito dos ocidentais diante dos povos "estranhos". É posicionamento agressivo porque infantilizado, obediente a impulsos imaturos, a crenças estreitas, a preconceitos ignorantes de sua inconsciência. Essa narrativa vai conduzir ao recrudescimento dos nacionalismos, dos obscurantismos, a um futuro mais fechado e, no limite, a regimes fascistas.

A segunda narrativa toma corpo quando escutamos o clamor de cientistas que vinham apontando a ameaça que hoje se tornou fato. Para citar um exemplo específico, o empresário norte-americano Bill Gates (fundador da Microsoft) havia afirmado, em março de 2015, na plataforma TED Talks: "não estamos preparados para uma próxima pandemia. Podemos ter ferramentas, mas elas precisam ser colocadas num sistema geral de saúde global, e precisamos de preparação. Então, acho que essa deveria, com certeza, ser uma prioridade" (GATES, 2015). Esse discurso vai conduzir ao fortalecimento de redes de cooperação além-fronteiras, ao incremento da educação e das ciências e a um futuro mais aberto. Pois ele confirma sinais que de muitos lados já nos chegavam indicando a disfuncionalidade do nosso estilo de vida, seja no campo dos desequilíbrios ecológicos, da economia que promove misérias, do consumismo cultural que pisoteia diversidades.

Essas duas narrativas não permanecerão estanques. Alguns elementos de uma precisam ser assimilados pela outra, pois enfim não há como deixar de questionar alguns procedimentos da parte da China, mas também não há como aceitar subserviências a controles centrais ou a programas neoliberais. Entretanto, espero que este esboço nos ajude a pensar.

Pois cabe a cada um de nós uma escolha entre essas duas linhas de pensamento e narrativa. E cabe a cada um de nós ajudar a tecer, com ações concretas, uma entre as várias modalidades práticas que essas tendências irão tomar.

Nestor Müller

Revista ALTERJOR

Grupo de Estudos Alterjor:Jornalismo Popular e Alternativo (ECA-USP)

Ano 10 Volume 02 Edição $22 \quad$ Juho- Dezembro de 2020

Avenida Professor Lúcio Martins Rodriģues, 443, Cidade Universitária, São Paulo, CEP: 05508-020 
foi convite sistemático ao lugar doméstico como estratégia de combate à propagação da pandemia do coronavírus. Entretanto, o empenho para o retiro coletivo evidenciou as periferias da miséria, do desconforto e do abandono. Ficou claro, no final de maio de 2020, que o vírus revelou os meandros da não-inclusão social. De um lado, os preservados. De outro, os expostos. Quanto mais se multiplicaram os benefícios para quem pôde estar dentro de casa, tanto mais se evidenciou a vulnerabilidade dos sem-teto, sem-identidade e sem-civilidade. Sobre o grupo dos excluídos a afirmação de Donatella Di Cesare, filósofa italiana e docente da Universidade de Roma, foi bem evidente.

Nestes locais vivem, ou melhor, sobrevivem os perdedores da globalização, e ali não chega o sistema de garantias e de segurança... essa outra humanidade (mas serão realmente 'humanos'?) estará inexoravelmente exposta a guerras, genocídios, fome, doenças, desnutrição, exploração sexual e novas formas de escravidão (DI CESARE, 2020: 43). 


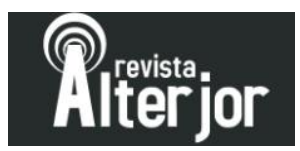

A pandemia ratificou os indefesos como possíveis contaminadores, ampliando a já longínqua dimensão social. Ou seja, uma sociedade em permanente estado de emergência médica, política, econômica, social e ambiental jamais será livre. Além do que, a interação somente com máquinas e telas dificultou os encontros culturais, artísticos e políticos, além das atividades escolares e universitárias. A pandemia do vírus trouxe à tona alguns descuidos estruturais de nosso país, como as condições desumanas de moradias, as deficiências de saúde pública, a degradação da natureza, o aumento do desemprego e a falta de preparo dos governantes.

Bolhas monitoradas por câmeras de segurança e protegidas por grades, alarmes, vidros blindados e muros - a cultura globalizada do pânico - disseminou o medo, ansiedade e ódio. Esses aspectos das forças obscuras são expressões da direita radical do presidente Jair Bolsonaro, que reivindica para si o papel de vítima. E ao mesmo tempo pratica a política bélica da destruição à constituição, saúde pública, educação, cultura, comunicação social, meio ambiente e universidade pública. Com provocações e xingamentos volta suas armas aos índios, negros, homossexuais, cientistas, jornalistas e progressistas. O Brasil dilacerado visou apenas o interesse econômico. Mesmo assim, deu na manchete do jornal Valor Econômico de São Paulo: "Brasil sai do radar do investidor estrangeiro" (VALOR ECONÔMICO, 2020: 1). A origem da queda do fluxo de capital externo apontou para a crise do coronavírus e seus impactos sobre a economia, mas sobretudo diante das "graves incertezas políticas alimentadas pelo governo". Seria tentar administrar o caos ocultando a realidade?

Já que a crise é oportunidade transformadora, desenvolver e problematizar a ressignificação do habitat intimista estimulou reflexões e ações. É a ideia de voltar para casa, de se olhar, de trazer nossa intuição e força interior. Com isso, imagens puderam sintetizar acontecimentos reais ou imaginários. A linguagem fotográfica, portanto, tornou-se instrumento para a inclusão de olhares cruzados e múltiplos. Essa investida me fez reativar o princípio de que "o olho é como uma câmera - ou melhor, a câmera é como um olho" (AVANCINI, 2010: $3)$.

A produção do ensaio fotográfico partiu do princípio de que o lar se constituiu espaço único e momentâneo para muita gente. Fez lembrar a criação literária do escritor Machado de Assis, quando se trancava dentro de casa e evitava abrir janelas e ver paisagens, mas sem jamais negar o cotidiano e os hábitos das ruas cariocas. Carlos Heitor Cony revelou traços do bruxo das letras na crônica "Machado - o romance carioca", publicado originalmente no Jornal do Brasil 


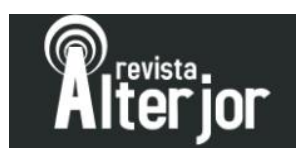

de 26 de setembro de 1959: "limita-se ao mínimo, ao essencial, transfigurando o exterior, não mera moldura de um fato ou sentimento, mas integrado no interior, coeso, uno" (CONY, 2019: 306).

De fato, as cenas fotografadas propõem a observação e a documentação dos recantos desse mundo interno. Este fotógrafo, para quem a experiência física do contato com o outro foi vedada, sentiu-se dominado pela nostalgia e recorreu a telas, filtros, representações, rebatimentos, reenquadramentos, distorções formais e fragmentos. O espaço domiciliar ocupado pelas telas - celulares, computadores, televisão e câmeras -, nas quais "tocamos" o mundo protegido, jamais pareceu tão imprescindível. Aproveitei a oportunidade para rever fotografias dispostas nas paredes ou nas capas de livros, mas com outro enfoque. Em 1974, o fotógrafo francês Henri Cartier-Bresson afirmou à entrevistadora Sheila Turner-Seed da revista Popular Photography: "para mim, todos os lugares são interessantes, até mesmo seu quarto" (CARTIER-BRESSON, 2015: 44).

A imagem remete a universos simbólicos ao trabalhar com memórias e narrativas que dão sentidos ao tempo presente. Por isso busquei a ressignificação do dispositivo fotografia, reutilizando todo o seu potencial expressivo para criar outras leituras. Assim, a janela da imaginação compareceu para promover características humanas do meio fotográfico. Momentaneamente, ele deixou de ser algo imensurável e inclassificável e se lançou para além dos discursos dominantes e homogeneizantes: artefato cultural, plástico e subjetivo.

O objetivo do ensaio foi reportar fotografias no ambiente doméstico pelo smartphone iPhone7. Apresento seis imagens, da figura 1 à figura 6. A metáfora da produção é integrar a lente do celular - espécie de olho atento - ao mundo filtrado, embaçado e distorcido em que vivemos. Convido o leitor a compartilhar esse processo de reflexão, buscando ampliar os limites do espaço confinado para caminhos mais abrangentes.

Atílio Avancini 


\section{Ritiejor}

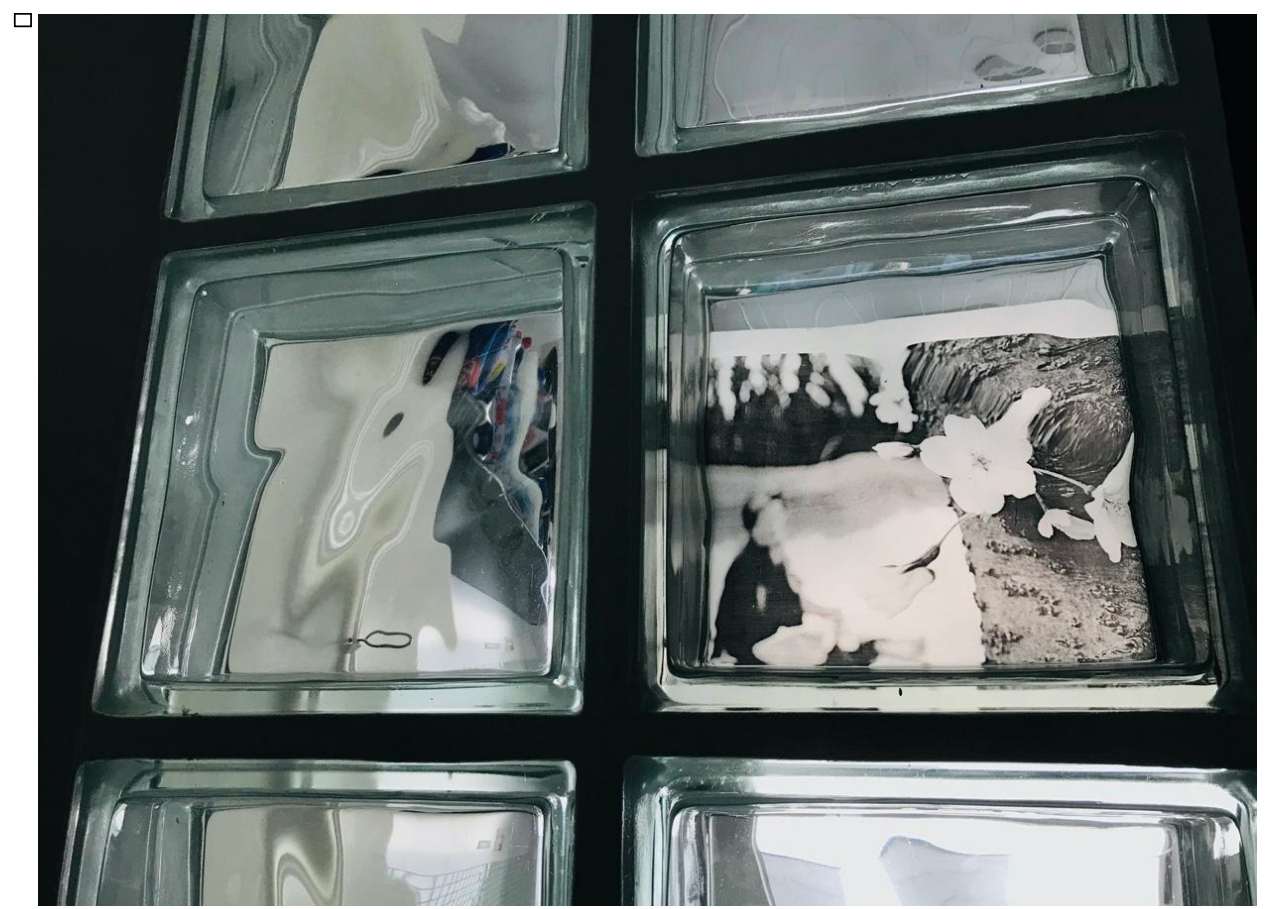

Figura 1. Foto Atílio Avancini. A partir de fotografia do autor. São Paulo (SP), 2020

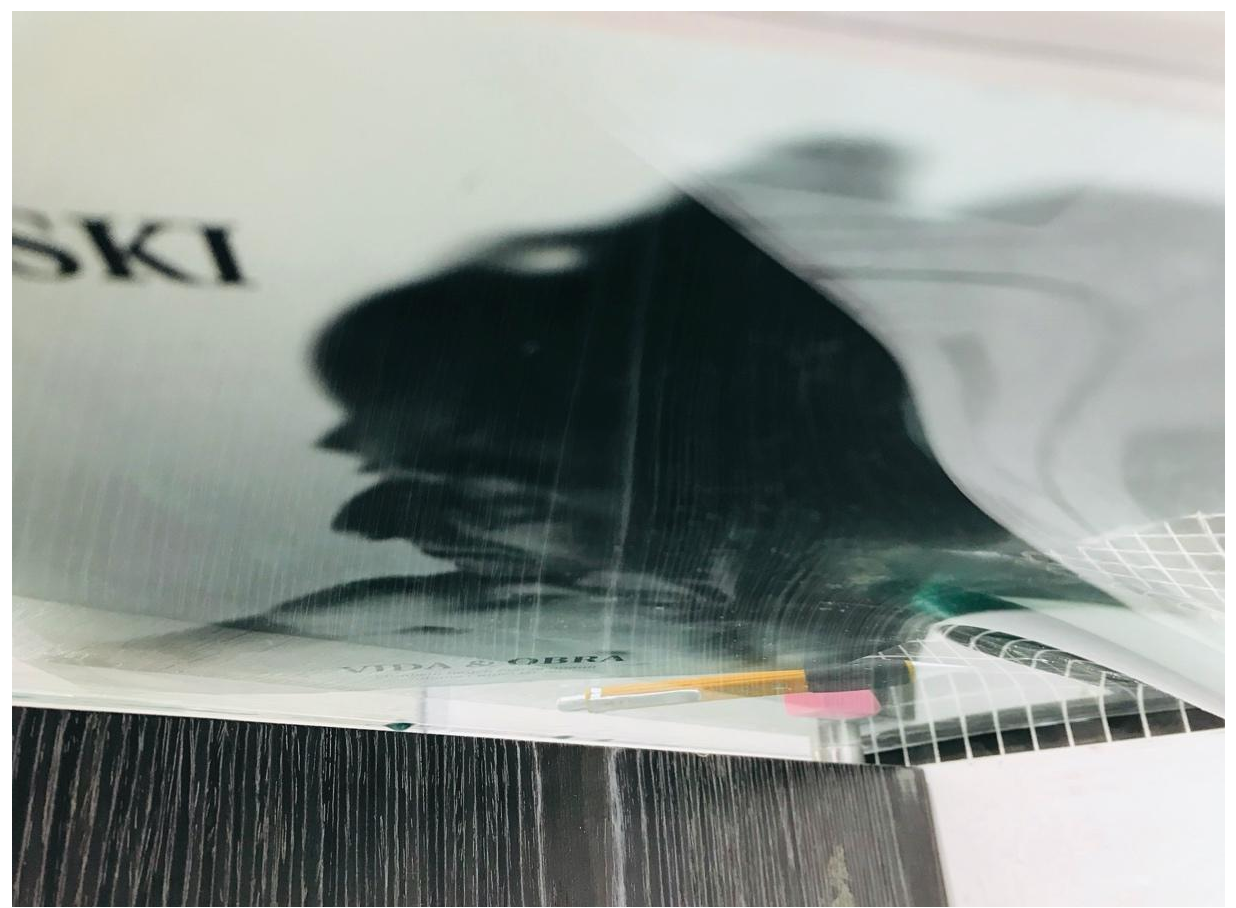

Figura 2. Foto Atílio Avancini. A partir de fotografia do autor (capa do livro Rolf Gelewski). São Paulo (SP), 2020

Revista AL TERJOR

Grupo de Estudos Alterjor:Jornalismo Popular e Alternativo (ECA-USP)

Ano 10 Volume 02 Edição $22 \quad$ Juho- Dezembro de 2020

Avenida Professor Lúcio Martins Rodriģues, 443, Cidade Universitária, São Paulo, CEP: 05508-020 


\section{Pirerijor}

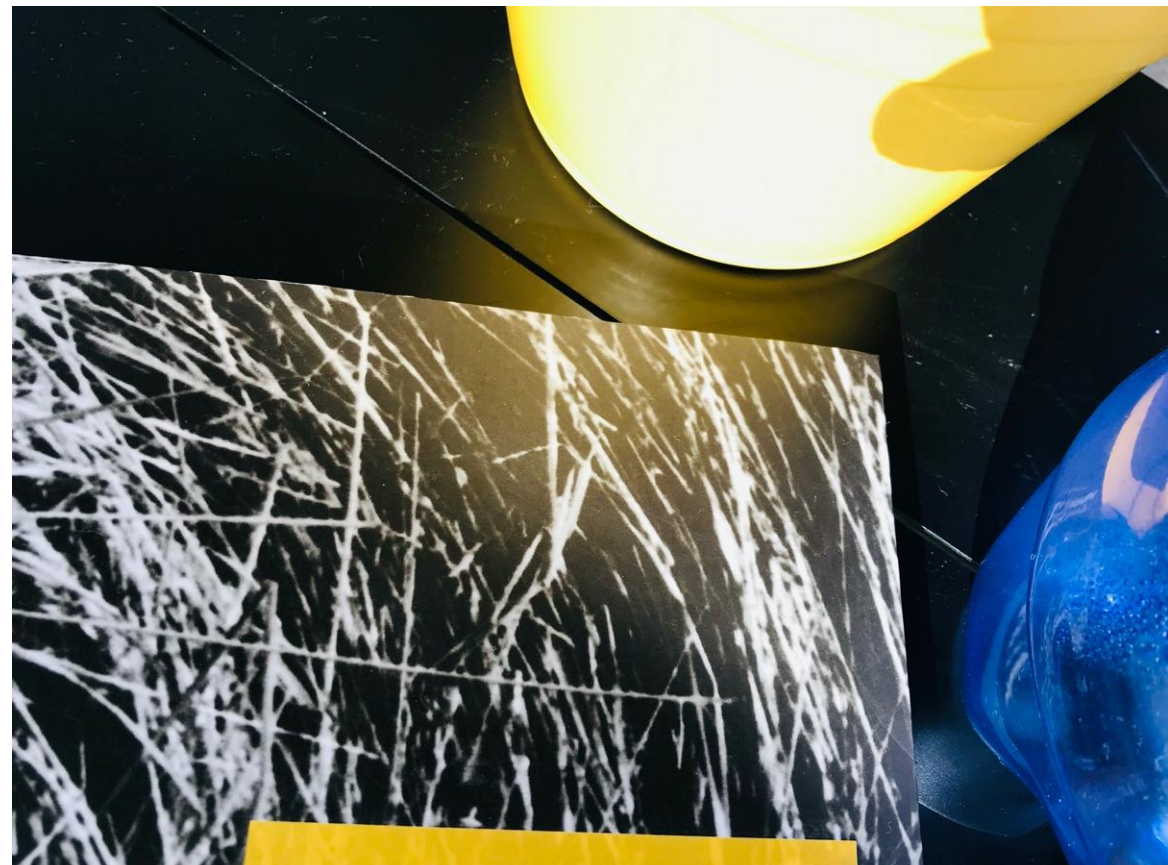

Figura 3. Foto Atílio Avancini. A partir de fotografia do autor (capa do livro Rastros). São Paulo (SP), 2020

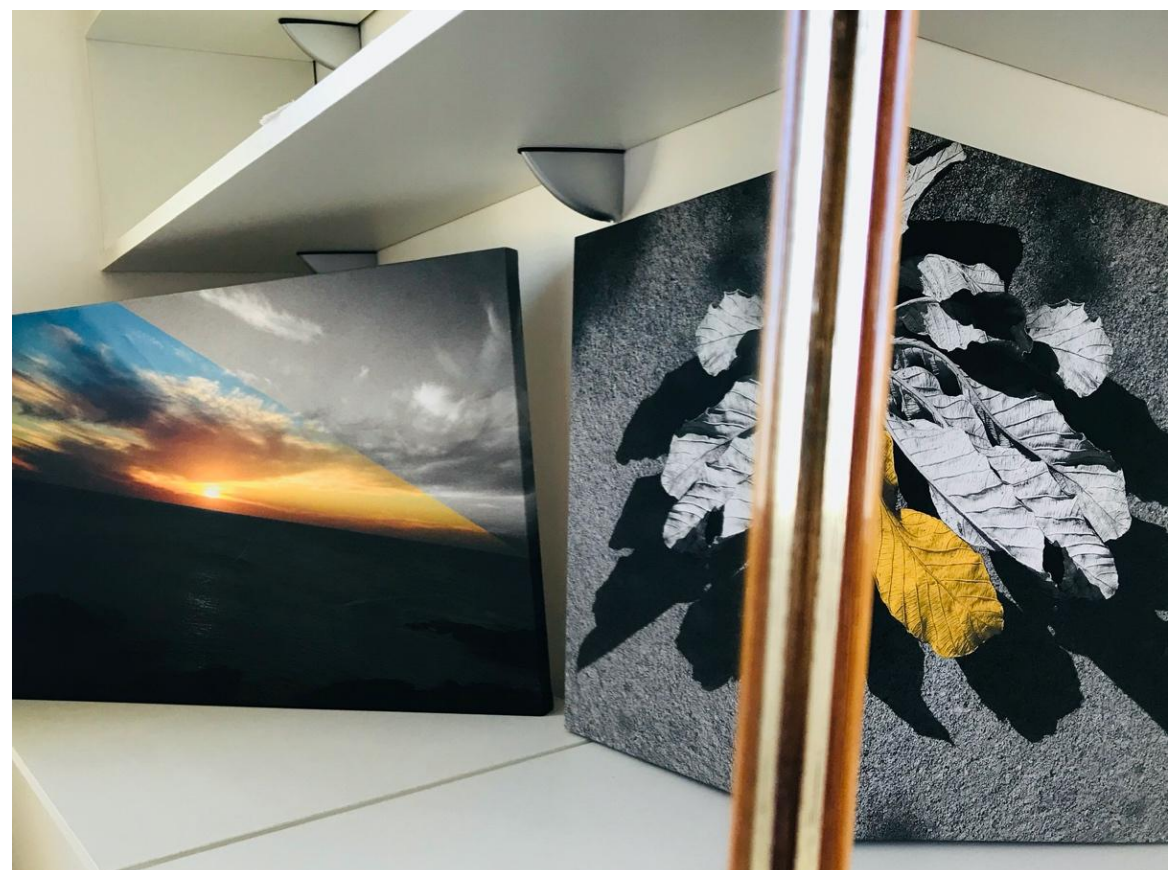

Figura 4. Foto Atílio Avancini. A partir de fotografias de Manuel Reis. São Paulo (SP), 2020

Revista AL TERJOR

Grupo de Estudos Alterjor:Jornalismo Popular e Alternativo (ECA-USP)

Ano 10 Volume 02 Edição $22 \quad$ Juho- Dezembro de 2020

Avenida Professor Lúcio Martins Rodrig̉ues, 443, Cidade Universitária, São Paulo, CEP: 05508-020 

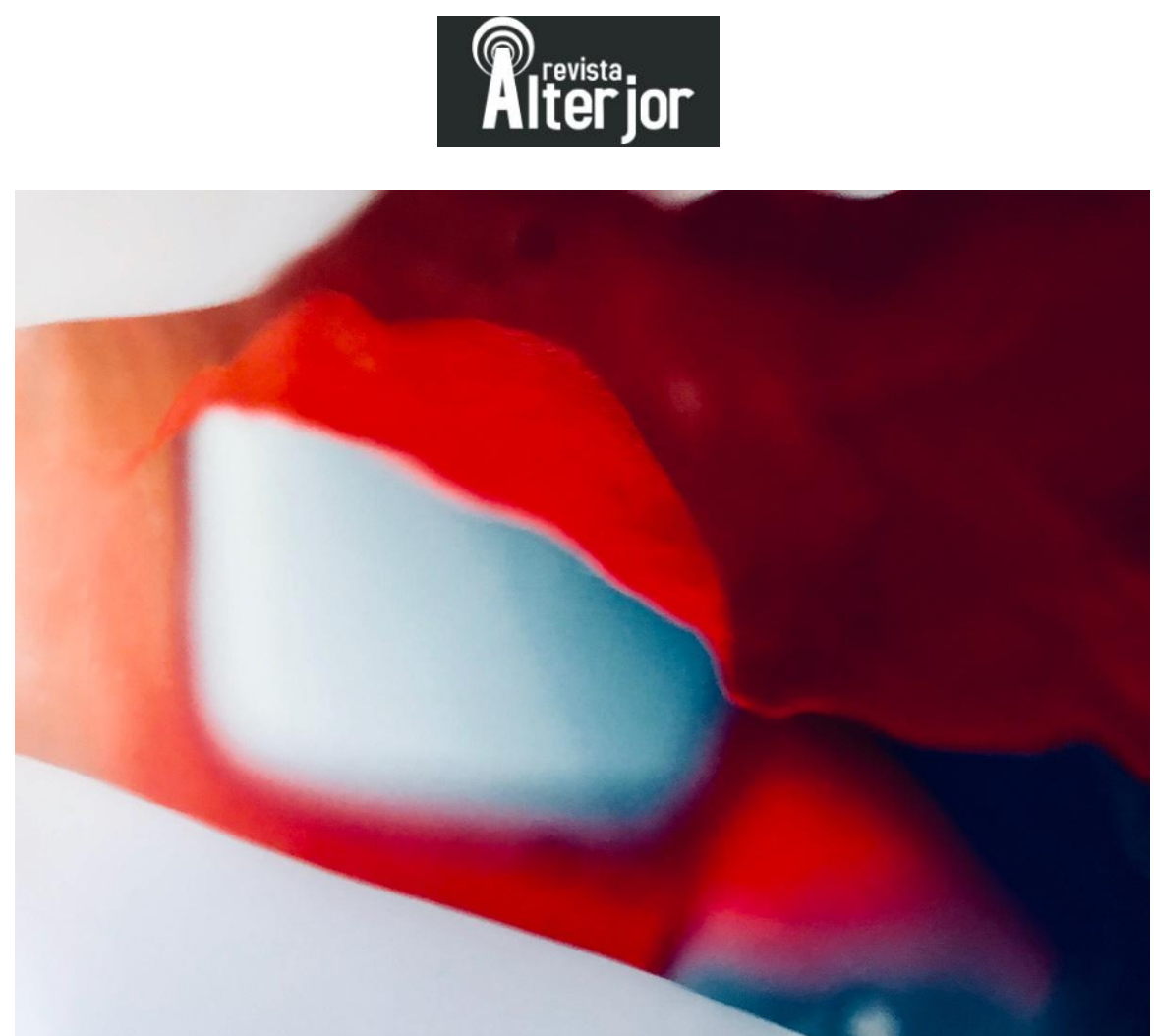

Figura 5. Foto Atílio Avancini. A partir de fotografia de Manuel Reis. São Paulo (SP), 2020

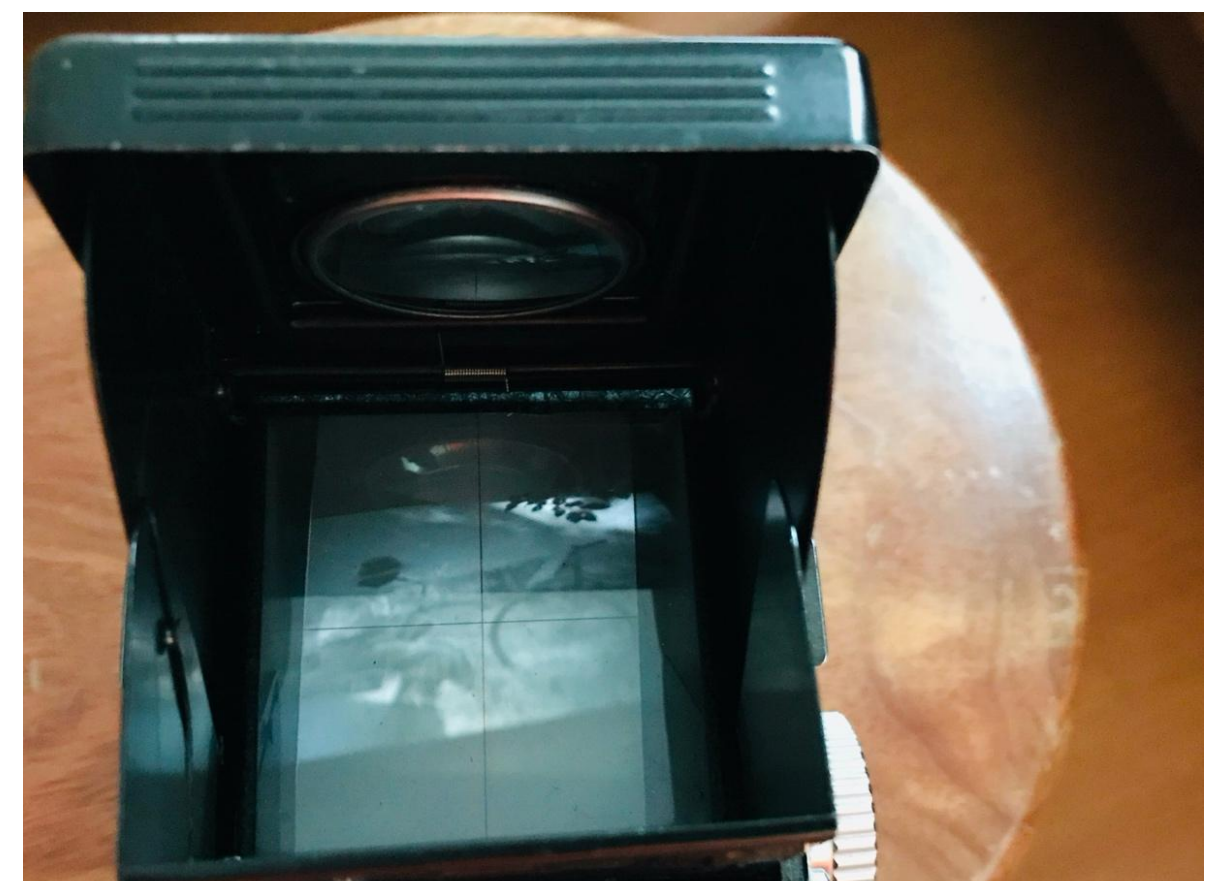

Figura 6. Foto Atílio Avancini. A partir de fotografia do autor. São Paulo (SP), 2020

Revista ALTERJOR

Grupo de Estudos Alterjor:Jornalismo Popular e Alternativo (ECA-USP)

Ano 10 Volume 02 Edição $22 \quad$ Juho- Dezembro de 2020

Avenida Professor Lúcio Martins Rodrig̉ues, 443, Cidade Universitária, São Paulo, CEP: 05508-020 


\section{Referências bibliográficas}

AVANCINE, S; AVANCINI, A. Rastros. São Paulo: Com-Arte, 2019.

AVANCINI, Atílio. Espelho da Vida: relato de viagem a partir de oficina de fotografia para formar pesquisadores indígenas do Museu Kuahi no Baixo Oiapoque. Revista Alterjor, São Paulo, julho-dezembro 2010, pp. 1-10.

Disponível em: http://www.revistas.usp.br/alterjor/article/view/88200/91078. Acesso em $29 / 05 / 2020$

CARTIER-BRESSON, Henri. "Existe Transcendência". In: CARTIER-BRESSON, Henri. Ver é um todo: entrevistas e conversas 1951-1998. São Paulo: Gustavo Gili, 2015.

CONY, Carlos Heitor. "Machado - o romance carioca". In: GUIMARÃES, H.; LEBENSZTAYN, I. Escritor por escritor: Machado de Assis segundo seus pares 1939-2008. São Paulo: Imprensa Oficial do Estado de São Paulo, 2019.

DI CESARE, Donatella. "O vírus soberano". Revista Piauí, Rio de Janeiro, abril 2020, pp. 4045. Disponível em: https://piaui.folha.uol.com.br/materia/o-virus-soberano/. Acesso em $20 / 05 / 2020$

GATES, Bill. A próxima epidemia? Não estamos preparados, alerta Bill Gates. Disponível em: http://www.mundodigital.net.br/index.php/destaque/12998-a-proxima-epidemia-nao-estamospreparados-alerta-bill-gates. Acesso em 30/03/2020.

TRUMP, Donald. Inteligência dos EUA tentou alertar Casa Branca sobre coronavírus em novembro. Disponível em: https://www.cnnbrasil.com.br/internacional/2020/04/08/inteligenciados-eua-tentou-alertar-casa-branca-sobre-coronavirus-em-novembro. Acesso em 30/03/2020.

VALOR ECONÔMICO. Brasil sai do radar do investidor estrangeiro. Jornal Valor Econômico, São Paulo, 27/ Maio de 2020, p. 1.

ZIMMERMANN, E.; PASSOS, J. Rolf Gelewski: vida e obra. Campinas: Autoral, 2020. 